\section{European Lake Drilling Programme (ELDP)}

The European Lake Drilling Programme (ELDP) was launched as an ESF (European Science Foundation) Scientific Programme by the ESF Executive Council in November 1995 for a period of five years, starting operations in January 1996. It is supported by the member organisations from Belgium, France, Germany, Norway, Poland, Sweden, Switzerland and The Netherlands.

Scientists involved plan to further the recovery and interpretation of high resolution lacustrine paleoclimatic and paleoenvironmental archives in Europe. As many sites have already been studied in detail by individual research teams, it has become an attractive challenge to pool these data from as many European regions as possible on a common calendar-year time scale to give answers to some of the key questions of PAGES.

Continental paleoclimate records are critical because they provide evidence of the impacts of past climatic changes that were relevant to human societies and their activities. Among these records, high resolution lake sediments have particular advantages for paleoclimatic reconstructions and modelling, as they are present in various different environments and geographic locations, they provide continuous and high-reso- lution records, they are archives for a large variety of climate- and environment-related proxies, they provide data needed for modelling climate changes, they give an enhanced continental perspective on paleoclimatic information and they contribute to land-sea-ice correlations.

The main activities of ELDP are built around major annual workshops to provide effective links between ongoing research programmes. Previous ELDP workshops have been organised in Le Bischenberg (France), in Cracow (Poland) on "European dimension of high resolution lacustrine records" and in Ptolemais (Greece) on "Mediterranean Lacustrine Records" - for the latter see the report below. The next workshop is planned for Lund (Sweden) on "Correlations of Late Weichselian and Holocene paleoenvironmental proxy data a comparison of independent timescales based on high-resolution lacustrine data" - see the calendar on the last page of this Newsletter. During ELDP workshops special efforts are devoted to the correlation of high resolution paleoenvironmental records across the European continent which are focussed along four main transects. For these transects regional working groups have been formed which are an integral part of ELDP. These working groups are related

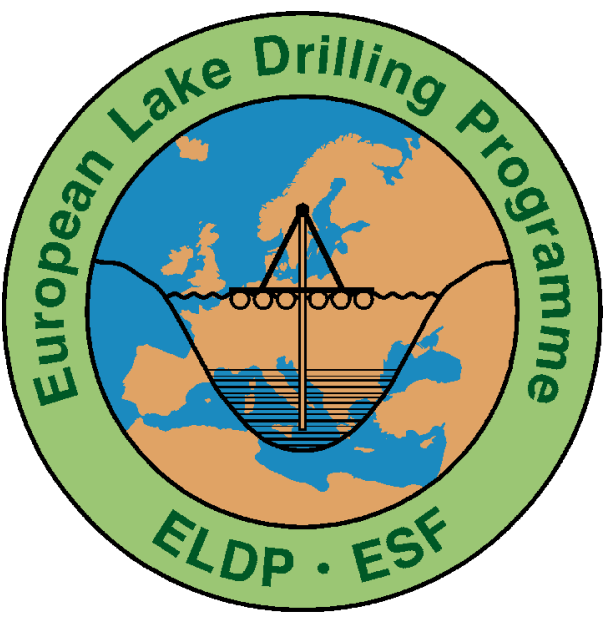

to "Northern Europe", the "Atlantic Transect" (see also working group report in the PAGES Newsletter 98-2, p. 11), "Central Europe" and "Southern Europe". An additional topical working group is related to "Climate Variability in Annual to Milankovich Frequency Bands".

For more information on the programme's progress and on recent developments, please visit the ELDP homepage at http://www.gfz-potsdam.de/pb3/ pb33/eldphome/.

\section{BeRnd ZoLITSCHKA}

GeoForschungsZentrum, Potsdam, Germany zoli@gfz-potsdam.de

\title{
Mediterranean Lacustrine Records
}

\author{
Ptolemals, Greece, October 14-18, 1998
}

The $3^{\text {rd }}$ international ELDP Workshop, entitled "Mediterranean Lacustrine Records" was held in Ptolemais, Greece, on October 14-18, 1998. The meeting attracted 34 participants from 12 European countries and two participants from Israel and Japan. It began with brief reports of the five different ELDP working groups: "Northern Europe" (I. Snowball), "Atlantic Transect" (S. Leroy), "Central Europe" (J. Merkt), "Southern Europe" (R. Julia) and "Climate Variability in Annual to Milankovich Frequency Bands" (J. Meulenkamp). These were followed by presentations concentrating on lacustrine records from the Mediterranean area covering the time span of marine oxy- gen isotope stages 1 to 5 or, roughly, the last 130,000 years. Talks included such topics as high resolution interglacial records, climatic fluctuations detected during the last glacial and their relation to similar events recorded in Greenland summit ice cores and marine sediment records, short-term climatic events during the late glacial and early Holocene, environmental changes during the last 2000 years, the application of tephra layers as time markers and as a correlation tool, biotic and abiotic responses to orbital and solar forcing, and climatic modelling. A mid-conference one day field trip was organised to the late $\mathrm{Neo}$ gene lacustrine sediments of the Ptolemais basin, providing an impressive ex- ample of the effects of orbital forcing in Milankovich and sub-Milankovich frequency bands to sedimentological and environmental processes.

Extended abstracts of almost all presentations and the excursion guide have been published as volume 1998/6 of Terra Nostra - Schriftenreihe der AlfredWegener-Stiftung. This volume can be ordered online at http://www.awstiftung.de/publikationen.htm.

\section{Bernd ZolitschKa}

GeoForschungsZentrum, Potsdam, Germany zoli@gfz-potsdam.de 